\title{
Comments
}

\section{SELF-REPRESENTATION IN CRIMINAL TRIALS: THE DILEMMA OF THE PRO SE DEFENDANT}

The prosecution of defendants who claim their trials are politically motivated ${ }^{1}$ has brought in its wake a subordinate but important issue-that of voluntary self-representation in criminal trials. Anyone accused of a serious crime ${ }^{2}$ in the United States can liave a lawyer. Although legal assistance in criminal trials was once a privilege of wealth, Gideon v. Wainwright ${ }^{3}$ now assures those without means that they will not be deprived of counsel simply because of their poverty. Thus the right to assistance of counsel has become a reality in the vast majority of prosecutions, whether the defendant pleads guilty or stands trial. ${ }^{4}$ Informal bar association and court procedures for appointing counsel, once the primary source of legal assistance for indigent defendants, now merely supplement the many public defender and legal-aid offices throughout the country. Not surprisingly, the vast majority of recent criminal defendants avail themselves of these resources. ${ }^{5}$

Despite the availability of counsel, a visible minority of the defendants who choose to contest their guilt either do not want counsel at trial or demand that they be allowed to participate in the conduct of

1. See text accompanying notes 134-52 infra.

2. The problem of delineating what counts as a "serious crime" is beyond the scope of this Comment. For a discussion of misdemeanor cases, see Junker, The Right to Counsel in Misdeameanor Cases, 43 WASH. L. REv. 685 (1968).

3. 372 U.S. 335 (1963).

4. Problems of representation in the guilty-plea process, which terminates approximately nine out of 10 criminal prosecutions without trial, are not considered in this Comment. See Tigar, Foreword to The Supreme Court, 1969 Term, 84 HARv. L. Rev. 1 (1970); The Supreme Court, 1969 Term, 84 HARv. L. Rev. at 148. See also North Carolina v. Alford, 400 U.S. 25 (1970).

5. Statistics on the incidence of self-representation are not available, but compared with the total number of defendants who go to trial, very few choose to represent themselves. See 1 L. Silverstein, Defensse of the Poor in Criminal Cases in American State Courts, A Field Study and Report 93 (1965). One indication of the desire for counsel can be inferred from federal data showing that the number of defendants represented by counsel under the Criminal Justice Act of 1964 rose from 15,671 in 1966 , to 27,060 in 1969 , while the number of criminal cases terminated in federal district courts during the same period rose from 30,644 to 32,406. See 1969 Administrative Office of the United States Courts, ANn. Rep. II-34, and Appendix on Payments made under the Criminal Justice Act. 
their defense. The case of Ruchell Magee and Angela Davis on charges of murder, kidnapping, and conspiracy offers one such illustration. ${ }^{\circ}$ During the pretrial proceedings, Magee refused the appointment of counsel to assist him. He consistently argued for the right to represent himself and was supported by his appointed counsel. ${ }^{7}$ Yet the court repeatedly denied his motions on the ground that Magee was not com-

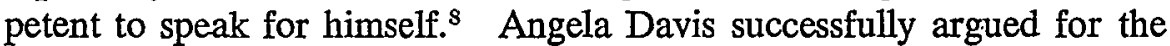
right to participate in her trial as co-counsel alongside her private attorneys. ${ }^{9}$ The basis for granting her motion, however, was not any state or federal constitutional right, but rather, a narrow finding that, in her case, "the cause of justice will be served and expeditious conduct of the Court's business will not be hampered."10

These deınands for self-representation raise fundamental questions concerning the right to assistance of counsel under the sixth amendment $^{11}$ and the requirements of procedural due process under the fifth and fourteenth amendments. The rationale of the right-to-counsel cases from Powell v. Alabama ${ }^{12}$ to Gideon is that a trial where the defendant cannot present his case effectively is fundamentally unfair and, therefore, a violation of due process of law. ${ }^{13}$ Furtherinore, one of

6. People v. Davis, No. 3744 (Cal. Super. Ct., Marin County, filed Nov. 10, 1970) [references to the reporter's transcripts of pretrial proceedings are hereinafter cited as Davis Transcript].

7. Davis Transcript 21 (May 5, 1971).

8. S.F. Examiner, Mar. 7, 1971, \$ A, at 26, col. 1. Magee was found incompetent on the basis of an intelligence test administered in San Quentin Prison which mea. sured his IQ at 75, and tests of his behaviour in prison and at other trials submitted by the prosecution. Davis Transcript 27 (Dec. 22, 1970). Magce contends that the test and information are inaccurate. On July 19,1971, his case was severed on motion of counsel for Angela Davis. Davis (clerk's) Transcript, Minute Order, at 186(3) (July 19, 1971). As of Oct. 18, 1971, Magee and Ernest L. Graves, his court-appointed legal advisor, were still pressing for another hearing to determine Magee's competence to participate in his defense.

9. Miss Davis presented her argument for co-counsel status on July 21, 1971. Davis Transcript (July 21, 1971). The motion was granted on July 27, 1971 [Davis Transcript 23-24 (July 27, 1971)], giving her the right to participate as co-counsel in the trial and pretrial proceedings.

10. Davis Transcript 23-24 (July 27, 1971). The court's finding is well within current California law. See People v. Mattson, 51 Cal. 2d 777, 336 P.2d 937 (1959), discussed in text accompanying notes 93-95 infra.

11. The sixth amendment provides:

In all criminal prosecutions, the accused shall enjoy the right to a speedy and public trial, by an impartial jury of the State and district wherein the crime shall have been committed, which district shall have been previously ascertained by law, and to be informed of the nature and cause of the accusation; to be confronted with the witnesses against him; to have compulsory process for obtaining witnesses in his favor, and to have the assistance of Counsel for his defence.

U.S. CoNST. amend. VI (emphasis added).

12. 287 U.S. 45 (1932).

13. See, e.g., Gideon v. Wainwright, 372 U.S. 335, 344 (1963); Adams v. United 
the primary societal values supported by the due process clauses is the reliability of the guilt-determining process ${ }^{14}$-its ability to convict the guilty and acquit the innocent. The related goals of reliability and fairness ordinarily require that a defendant have the assistance of counsel in countering the resources aligned against him by the state.

Nevertlieless, the sixth amendment itself guarantees only assistance; it "does not force a lawyer upon a defendant."15 For defendants who seek to vindicate political or moral beliefs in their trials, reliability in the criminal process may be a relatively minor interest. ${ }^{16}$ More important, political and nonpolitical defendants may believe that reliability, and therefore fairness, can only be achieved through self-representation, with or without the assistance of counsel. The guarantee of legal assistance under the sixtli amendinent is primarily intended for the benefit of the individual defendant, and only through him to serve society's broader interests: "[T]lie procedural safeguards of the Bill of Rights are not to be treated as meclianical rigidities. What were contrived as protections for the accused slould not be turned into fetters." $" 17$

States ex rel. McCann, 317 U.S. 269, 279 (1942); Betts v. Brady, 316 U.S. 455, 473 (1942); Powell v. Alabama, 287 U.S. 45, 71 (1932). In Powell v. Alabama, Justice Sutherland eloquently explained why counsel is normally necessary to guarantee the defendant an effective presentation:

The right to be heard would be, in many cases, of little avail if it did not comprehend the right to be lieard by counsel. Even the intelligent and educated layman has small and sometimes no skill in the science of law. If clrarged with crime, he is incapable, generally, of determining for himself whether the indictment is good or bad. He is unfamiliar with the rules of evidence. Left without the aid of counsel lie may be put on trial without a proper charge, and convicted upon incompetent evidence, or evidence irrelevant to the issue or otherwise inadmissible. He lacks both the skill and knowledge adequately to prepare his defense, even though he have a perfect one. He requires the guiding hand of counsel at every step in the proceedings against him. Without it, though he be not guilty, he faces the danger of conviction because he does not know how to establish his innocence. If that be true of men of intelligence, how much more true is it of the ignorant and illiterate, or those of feeble intellect.

287 U.S. at 68-69.

14. Kadish, Methodology and Criteria in Due Process Adjudication, 66 YALE L.J. 319,346 (1957).

15. Adams v. United States ex rel. McCann, 317 U.S. 269, 279 (1942).

16. To say that such a purpose is an improper use of the judicial system is overly simplistic. If an allegedly criminal act is motivated by moral or political beliefs, those beliefs may be relevant both in determining the defendant's intent and, perhaps, as evidence of imitigating circumstances. Once it is recognized that the defendant's political beliefs and activities are relevant, Angela Davis' argument as to why she should be allowed to represent herself becomes credible: "I alone, I feel, can competently challenge witnesses and evidence pertaining to my political behefs and activities, because no one is as intimately acquainted with my politics as I am." Davis Transcript 39 (July 21, 1971). See text accompanying notes 148-52 infra.

17. Jolnson v. Zerbst, 304 U.S. 458, 468 (1938). A defendant's decision to represent himself may or may not appear rational, but respect for his individuality requires 
No conflict exists between the fundamental values of fairness to the individual and rehiability of the guilt-determining process in cases where the defendant wants to participate actively in the conduct of his defense but also desires the assistance of counsel. Ironically, however, this seemingly ideal means of reconciling two potentially conflicting values is not recognized under state or federal law as a prerogative of the defendant. ${ }^{18}$ Although courts frequently appoint advisory or standby counsel to aid pro se defendants, ${ }^{10}$ it remains within the discretion of trial judges to impose an either-or choice on defendants who want to represent themselves.

Part I of this Comment analyzes the statutory and constitutional bases under federal and state law for allowing trial judges the discretion to impose an absolute choice between representation by counsel and self-representation. Part II examines the reasons why different kinds of defendants want to represent themselves, and, in so doing, questions a number of assumptions about professional representation supporting the widespread belief that every defendant should have a lawyer. In part III, a pragmatic argument is made froin the perspective of the criminal law professionals-judges and attorneys-in support of providing legal assistance to defendants who want to represent themselves.

\section{Legal Problems of Self-Representation}

\section{A. Availability of the Right: Federal Courts}

Self-representation is available to criminal defendants in federal court by statute and, arguably, as a constitutional right. The Judiciary Act of $1789^{20}$ guaranteed that "parties may conduct their own case personally or by counsel . . .."21 The same guarantee currently exists in substantially the same language under 28 U.S.C. $\$ 1654 .{ }^{22}$ As

that the choice remain with him, at least until he demonstrates an inability to choose. As Professor Kadish wrote: "The ideal of man's individuality which, after all, is what infuses meaning into the concept of freedom, is an emotional and personal as well as an intellectual affair." Kadish, supra note 14, at 347. See also Laub, The Problem of the Unrepresented, Misrepresented and Rebellious Defendant in Criminal Court, 2 DuQUESNE L. REV. 245, 256 (1964): "DD]efending a charge of crime is so personal and serious a matter that society has no legal or moral right to invade the cloister of the defendant's considered discretion."

18. See text accompanying notes 20-116 infra.

19. Mayberry v. Pennsylvania, 400 U.S. 455 , 466-68 (1971) (Burger, C.J., concurring).

20. Ch. 20, 1 Stat. 73 (1789).

21. Id. $\$ 35,1$ Stat. 92 .

22. "In all courts of the Umited States the parties may plead and conduct their own cases personally or by counsel as, by the rules of such courts, respectively, are per- 
a purely statutory guarantee, the right of self-representation has significant limitations. Unlike a constitutional right, notice of the right need not be given; ${ }^{23}$ its application does not extend to state court proceedings; and prejudice to the defendant must be shown in order to obtain a reversal on the ground that the right was improperly denied. Furthermore, the sound discretion of the trial court determines whether or not the right will be recognized, especially when it is invoked after the trial has commenced. ${ }^{24}$ Most important, a defendant lias no riglit to defend pro se and simultaneously to insist on representation by counsel. ${ }^{25}$ Given these limitations of its statutory basis, the right to self-representation can be effective only if it is grounded in the Constitution.

The Supreme Court lias never clearly held that the right to defend pro se is required by the Constitution, but several times it has referred to the right as if it were. In Carter $v$. Illinois ${ }^{26}$ the Court said: "[N]either the historic conception of Due Process nor the vitality it derives from progressive standards of justice denies a person the right to defend himself or to confess guilt." The Court was elaborating on a dictum from Adams v. United States ex rel. McCann, ${ }^{27}$ where, in analyzing the conditions under which counsel could be waived, the Court said:

The right to assistance of counsel and the correlative right to dispense with a lawyer's help are not legal formalisms. They rest on considerations that go to the substance of an accused's position before the law. ... [T] [he Constitution does not force a lawyer upon a defendant. ... He may waive his Constitutional right to assistance of counsel if he knows what he is doing and his choice is made with open eyes. . . . ${ }^{28}$

mitted to manage and conduct causes therein." 28 U.S.C. $\$ 1654$ (1970). See also FeD. R. CRIM. P. 44(a): "Every defendant who is unable to obtain counsel shall be entitled to have counsel assigned to represent him at every stage of the proceedings from his intial appearance before the commissioner or the court through appeal, unless he waives such appointment."

23. Brown v. United States, 264 F.2d 363, 365 (D.C. Cir.), cert. denied, 360 U.S. 911 (1959).

24. See, e.g., United States v. Mitchell, 137 F.2d 1006 (2d Cir. 1943); Seale v. Hoffman, 306 F. Supp. 330, 332 (N.D. Ill. 1969). But see Reynolds v. United States, 267 F.2d 235, 236 (9th Cir. 1959).

25. Shelton v. Umited States, 205 F.2d 806 (5th Cir.), petition for cert. dismissed on petitioner's motion, 346 U.S. 892 (1953), motion to vacate denied, 349 U.S. 943 (1955).

26. 329 U.S. 173, 174 (1946); accord, More v. Michigan, 355 U.S. 155, 161 (1957). See also United States v. Odom, 423 F.2d 875, 877 (9th Cir. 1970); Lowe v. United States, 418 F.2d 100, 103 (7th Cir. 1969); United States v. Sternman, 415 F.2d 1165, 1169 (6th Cir. 1969); Arnold v. United States, 414 F.2d 1056, 1058 (9th Cir. 1969); Hodge v. United States, 414 F.2d 1040, 1052 (9th Cir. 1969).

27. 317 U.S. 269 (1942).

28. 317 U.S. at 279 (emphasis added). 
The "correlative right" language was repeated in subsequent cases, ${ }^{20}$ but it has never been the basis for a holding by the Court. ${ }^{30}$

However, a number of circuit courts of appeals read the Court's dictum as law. ${ }^{31}$ The leading case holding self-representation to be a constitutional right is United States $v$. Plattner. ${ }^{32}$ There the defendant appealed the denial of a writ of error corain nobis arising from his conviction for transporting a stolen notor vehicle in interstate coinmerce. $^{33}$ The defendant had clearly requested permission to represent himself at the coram nobis proceeding, but the court refused on the ground that the defendant was not schooled in the law. ${ }^{34}$ The Second Circuit reversed, holding that the defendant "on the trial of a criminal case" has a right to conduct and manage his own case pro se, and that that right arises "out of the Federal Constitution and [is] not the mere product of legislation or judicial decision." ${ }^{35}$

The court reasoned that implicit in the fifth and sixth amendment guarantees "is the right of the accused personally to manage and conduct his own defense in a criminal case." 36 The sixth amendment right to counsel was intended to safeguard the accused's right to due process of law. "This safeguard was surely not intended to himit in any way the absolute and primary right to conduct one's own defense in propria persona." 37 The court found support for this determination in the language of Adams and in an interpretation of the Judiciary Act of 1789 as giving "more elaborate expression to the meaning of the terse language of the Bill of Rights. . . .".38

The Second Circuit ruled in Plattner that prejudice need not be

29. Carter v. Illinois, 392 U.S. 173, 174 (1946); Moore v. Michigan, 355 U.S. 155, 161 (1957).

30. The Court has consistently denied certiorari to cases raising this issue. See, e.g., United States ex rel. Davis v. McMann, 386 F.2d 611 (2d Cir. 1967), cert. denied, 390 U.S. 958 (1968); United States v. Llanes, 374 F.2d 712 (2d Cir.), cert. denied, 388 U.S. 917 (1967); United States v. Burkeen, 355 F.2d 241 (6th Cir.), cert. denied, 384 U.S. 957 (1966); United States v. Abbamonte, 348 F.2d 700 (2d Cir. 1965), cert. denied, 382 U.S. 982 (1966); United States v. Bentvena, 319 F.2d 916 (2d Cir.), cert. denied, 375 U.S. 940 (1963); Cleveland v. United States, 322 F.2d 401 (D.C. Cir.), cert. denied, 375 U.S. 884 (1963); Coleman v. Smith, 166 F. Supp. 934 (E.D. Va.), appeal dismissed, 260 F.2d 518 (4th Cir. 1958), cert. denied, 359 U.S. 946 (1959).

31. E.g., Lowe v. United States, 418 F.2d 100, 103 (7th Cir. 1969); United States v. Sternman, 415 F.2d 1165, 1169 (6th Cir. 1969); Arnold v. United States, 414 F.2d 1056, 1058 (9th Cir. 1969); United States v. Plattner, 330 F.2d 271, 273 (2d Cir. 1964).

32. 330 F.2d 271 (2d Cir. 1964).

33. 18 U.S.C. $\$ \$ 2,2312$ (1970).

34. 330 F.2d at 273 .

35. Id.

36. Id. at 274.

37. Id.

38. Id. See also note 22 supra. 
demonstrated to warrant a reversal when a defendant is not allowed to represent himself, ${ }^{39}$ and in United States ex rel. Maldonado v. Denno ${ }^{40}$ held that the right to self-representation is applicable in state trials as well as in federal prosecutions. ${ }^{41}$ Further, a clear record of the defendant's choice in the matter of representation should be made through a recorded colloquy with the presiding judge. ${ }^{42}$ If the defendant chooses to represent himself, he must indicate his choice unequivocally ${ }^{43}$ at the outset of the proceedings. ${ }^{44}$ The most important practical aspect of the right to defend pro se, however, was not clarified in Plattner or Maldonado. Neither the Second Circuit nor any other federal court has held that the right extends to simultaneous representation by counsel in an advisory capacity and pro se. In fact, United States v. Mitchell ${ }^{45}$ ex-

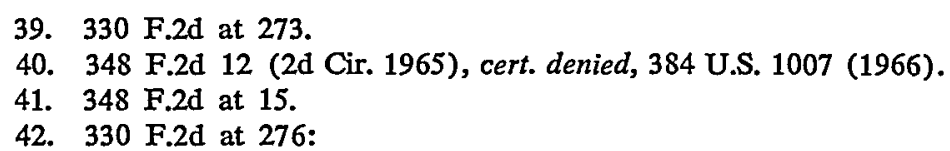

[I] $t$ is incumbent upon the presiding judge, by recorded colloquy with the defendant, to explain to the defendant: that he has the choice between defense by a lawyer and defense pro se; that, if he has no means to retain a lawyer of his own choice, the judge will assign a lawyer to defend him, without expense or obligation to him; that he will be given a reasonable time within which to make the choice; that it is advisable to have a lawyer, because of his special skill and training in the law and that the judge believes it is in the best interest of the defendant to have a lawyer, but that he may, if he elects to do so, waive his right to a lawyer and conduct and nanage his defense himself.

43. United States ex rel. Maldonado v. Denno, 348 F.2d 12, 15 (2d Cir. 1965). "If an uneqnivocal request were not required, convicted criminals would be given a ready tool with which to upset adverse verdicts after trials at which they had been represented by counsel." Id. at 16. Cf. United States v. Davis, 260 F. Supp. 1009, 1020 (E.D. Tenn. 1966). Another basis for requiring defendant's request to be unequivocal is the fundamental nature of the right to counsel. See, e.g., Von Moltke v. Gillies, 332 U.S. 708, 723 (1948) (waiver of counsel occurring contenuporaneously with a plea of guilty): "To discharge this duty properly in light of the strong presunption against waiver of the constitutional right to counsel, a judge must investigate as long and as thoroughly as the circumstances of the case before him deniand. . . ."

44. To the extent that the accused must claim his right to defend pro se at the outset of the proceedings, the right is not "absolute and priniary." United States v. Plattner, 330 F.2d 271, 274 (2d Cir. 1964). Plattner does "not reach the case where a defendant in the midst of a criminal trial seeks to dismiss his lawyer and for the balance of the trial inanage and conduct his own defense pro se" [id. at 277], but many other federal cases do consider the problem. Once the trial has begun, it is within the presiding judge's discretion to balance the legitimate interests of the defendant in proceeding pro se against the danger of disrupting the trial. See, e.g., United States v. Catino, 403 F.2d 491, 497 (2d Cir. 1968); United States ex rel. Maldonado v. Denno, 348 F.2d 12, 15 (2d Cir. 1965); United States v. Bentvena, 319 F.2d 916, 938 (2d Cir. 1963); Butler v. United States, 317 F.2d 249, 258 (8th Cir.), cert. denied, 375 U.S. 838 (1963); Sanchez v. United States, 311 F.2d 327, 333 (9th Cir. 1962); Urited States v. Dennis, 183 F.2d 201, 234 (2d Cir. 1950); United States v. Birrell, 286 F. Supp. 885, 897 (S.D.N.Y. 1968). The policies underlying the distinction between invoking the right to defend pro se at the outset and once the trial has begun are criticized in Grano, The Right to Counsel, 54 MinN. L. Rev. 1175, 1181-84 (1970).

45. 137 F.2d 1006 (2d Cir. 1943). 
plicitly states that "those rights cannot be both exercised at the same time." ${ }^{96}$

Neither is the Plattner view accepted in all federal courts. ${ }^{47}$ In United States v. Davis, ${ }^{48}$ for example, a district court said:

The validity of the deduction that the right to defend oneself without the assistance of counsel is a constitutional right is questionable. All that has really been said by the Supreme Court is that the Sixth Amendment does not prohibit the right of self-representation. ${ }^{40}$

46. Id. at 1010. The Mitchell court was construing the statutory right under 28 U.S.C. $\$ 1654$ (1970). See also United States v. Private Brands, Inc., 250 F.2d 554, 557 (2d Cir. 1957). Brasier v. Jeary, 256 F.2d 474, 476 (8th Cir. 1958), points out that the disjunctive language of the statutory right [see note 22 supra], which has been re-enacted several times without substantial change, is "highly persuasive" of the nonexistence of simultaneous rights. Shelton v. United States, 205 F.2d 806, 813 (5th Cir.), petition for cert. dismissed on petitioner's motion, 346 U.S. 892 (1953), motion to vacate denied, 349 U.S. 943 (1955), upheld the conviction of a pro se defendant who had requested and been denied advisory counsel, saying that the defendant had no constitutional right both to represent himself and to have counsel appointed to help him.

47. See, e.g., Van Nattan v. United States, 357 F.2d 161 (10th Cir. 1966); Butler v. United States, 317 F.2d 249 (8th Cir.), cert. denied, 375 U.S. 838 (1963); Brown v. United States, 264 F.2d 363 (D.C. Cir.), cert. denied, 360 U.S. 911 (1959). The Ninth Circuit has, however, accepted the logic and holding of Plattner. In a pre-Plattner decision, the court reversed the conviction of a college professor who had made a specific and unequivocal request three days before trial that he be allowed to conduct his own defense. Although no prejudice was shown by the trial court's refusal to allow defense pro se, the conviction was reversed on the authority of Duke v. United States, 255 F.2d 721 (9th Cir.), cert. denied, 357 U.S. 920 (1958), which held:

There are two principles which are founded on reason and authority in this field to which this Court gives full weight. First, an accused has an unquestioned right to defend himself [citing 28 U.S.C.A. $\$ 1654$ ]. Second, an accused should never have counsel not of his choice forced upon him. . . .

Id. at 724, quoted in Reynolds v. United States, 267 F.2d 235, 236 (9th Cir. 1959).

Since 1964 the Ninth Circuit has cited and followed Plattner several times. See, e.g., Arnold v. United States, 414 F.2d 1056 (9th Cir. 1969); Hodge v. United States, 414 F.2d 1040 (9th Cir. 1969); Bayless v. United States, 381 F.2d 67 (9th Cir. 1967). In Arnold, an accused bank robber told the trial judge on the morning trial was to commence that he preferred to defend himself. Although he had no complaints against his court-appointed counsel, he explained in a two-hour colloquy with the court and counsel that he had been "burnt" twice by appointed counsel and had been studying law for a year in Leavenworth Penitentiary. The court allowed the accused to defend himself. On appeal of his conviction, Arnold claimed that he had not made a valid waiver of counsel under Von Moltke v. Gillies, 332 U.S. 708 (1948). The court dismissed that contention, ruling that the language of Von Moltke was directory only. 414 F.2d at 1058. The court went on to note:

[A defendant has] a correlative constitutional right to refuse the advice or interference of counsel and to present his own case. A court has no more right to force an attorney on a defendant than it has to iguore the sixtl amendment right to counsel.

Id.

48. 260 F. Supp. 1009 (E.D. Tenn. 1966).

49. Id. at 1019. The court went on to hold that because the record did not clearly reflect that the defendant had made an unequivocal request to defend limself, 
Ultimately the Supreme Court must resolve this conflict in the circuits over the constitutional status of self-representation. However, of the factors traditionally weighed in constitutional analysis, none gives a clear indication of what the Court's determination will be. The language of the sixth amendment guarantees only the "assistance of Counsel." $"{ }^{50}$ Plattner and dicta in earlier Supreme Court opinions ${ }^{51}$ reason that the guarantee of assistance "does not justify forcing counsel upon an accused who wants none." "w2 This reasoning is compelling in the light of a lawyer's inability to confer the traditional benefits of counsel ${ }^{53}$ on a defendant who refuses to cooperate. An attorney cannot help achieve a fundamentally fair trial for the defendant, nor can lie help the judicial system process the defendant expeditiously, when the trust and confidence requisite to the traditional lawyer-client relationship are missing.

Plattner argues further that the language of the Judiciary Act of 1789 was meant to give "more elaborate expression to the meaning of the terse language of the Bill of Rights ...." H4 However, if substantially the same men drafted the Bill of Rights and the Judiciary Act at the same time, an equally plausible inference suggests that the different treatment of right to counsel and self-representation in the two documents was intentional, that is, that the framers did not intend to make self-representation a constitutional right. A fortiori there would then be no constitutional right to simultaneous self-representation and counsel.

A historical analysis of right to counsel in the late 18th century is equally imconclusive. ${ }^{55}$ Arguably, the sixth amendment guarantee was drafted in a setting where self-representation was more the rule than the exception. Hence, the guarantee of professional assistance was intended to supplement a defendant's ability to speak for himself. Even if this is correct, however, the force of the the argument diminishes somewhat with the changes in rules of evidence and procedure between 1789 and 1971. As one writer points out, a defendant now can be a witness in his own behalf, and he does not have the common law

because "there was considerable evidence that defendant was at least emotionally disturbed" and thus was not clearly capable of knowingly and intelligently waiving his right to counsel, and further, because he suffered no prejudice by the denial and would probably liave disrupted the trial, he was properly denied the right to represent himself. Id. at 1021.

50. See note 11 supra.

51. See text acconipanying notes 26-30 supra.

52. Moore v. Michigan, 355 U.S. 155, 161 (1957).

53. See Justice Sutherland's description of these benefits in note 13 supra.

54. $330 \mathrm{~F} .2 \mathrm{~d}$ at 274.

55. Grano, supra note 44 , at 1192-93. 
opportunity to make a separate statement to the jury. ${ }^{56}$ Of course, he must face the risks of cross-examination if he testifies. ${ }^{57}$

Perhaps the most difficult argument to overcome in establishing self-representation as a constitutional riglit is the logic and lolding of Singer v. United States. ${ }^{58}$ In Singer, the Warren Court upheld the validity of Rule 23(a) of the Federal Rules of Criminal Procedure, which conditions the waiver of a jury trial on the consent of the government and the court. ${ }^{59}$ The petitioner argued that the sixth amendment confers a correlative right to waive the jury trial guarantee and that this could not be taken away by the Federal Rules. In concluding that no such right exists, the Court said: "The ability to waive a constitutional right does not ordinarily carry with it the right to insist upon the opposite of that right." ${ }^{\text {60 }}$ If that language were the holding, a pro se defendant would have a difficult argument to make. Defendants have a right to assistance of counsel under the sixth amendment, but they have no explicit constitutional right to speak for themselves. Unless the Plattner and Adams logic of an implicit right is accepted, a defendant would be arguing solely for the right to insist upon the opposite of the sixth amendment guarantee-that is, for the right not to have the assistance of counsel. However, the holding in Singer was restricted to sustaining Rule 23(a), which deals with jury trials and not right to counsel.

Furthermore, the constitutional language guaranteeing the right to counsel is significantly different from that which establishes jury trial. In addition to the provision of the sixth amendment guarantceing "the right to a speedy trial by an impartial jury," the Constitution requires that "Trial of all Crimes . . . shall be by Jury . . .."11 No similar directory language exists with regard to the right to counsel: the body of the Constitution is silent, and the sixth amendment guarantees only assistance. Consequently, the Court could not point to the language of the Constitution with the same assurance for the proposition that denial of the right to self-represenation in favor of exclusive representation by counsel leaves the defendant with "the very thing that the Constitution guarantees him." 22

56. Id. at 1194.

57. See text accompanying notes $133-45$ infra.

58. 380 U.S. 24 (1965).

59. "Cases required to be tried by jury shall be so tried unless the defendant waives a jury trial in writing with the approval of the court and the consent of the government." FED. R. CRIM. P. 23 (a).

60.380 U.S. at 34.

61. "The trial of all Crimes, except in Cases of Impeachment, shall be by Jury. . . ." U.S. CoNsT. art. III, \& 2, cl. 3.

62. In light of the Constitution's emphasis on jury trial, we find it difficult to 
The Singer opinion recognizes a difference between the right to counsel and the right to a jury trial. Waiver of counsel is mentioned as being "subjected to reasonable procedural regulations" under Rule 44. ${ }^{\circ 3}$ Yet, it is not one of the rights that, like jury trial, does "not ordinarily carry with it the right to insist upon the opposite of that right."64 Finally, the Court found it "difficult to understand how the petitioner can submit the bald proposition that to compel a defendant in a criminal case to undergo a jury trial against his will is contrary to his right to a fair trial or due process."65 Yet, with respect to right to counsel, the Court has in several cases exphicitly said that "the Constitution does not force a lawyer upon a defendant. He may waive his Constitutional right to assistance of counsel if he knows what he is doing and his choice is made with eyes open."60

To sum up, the constitutional arguments for allowing defendants to represent themselves and to have the assistance of counsel while representing themselves are very much the same. Most persuasive are the language of the sixth amendment, guaranteemg only assistance, and the historical setting in which that guarantee was drafted. ${ }^{67}$ Perhaps the most difficult argument against simultaneous representation points to the language of the Judiciary Act as providing for an either-or choice, thus indicating the intent of the framers to limit the forms of self-representation. But the corollary to this either-or interpretation is that in writing the Judiciary Act the framers were amplifying the terse language of the sixth amendment. ${ }^{68}$ Hence, while a right to simultaneous representation might be denied, a clear constitutional right to self-representation is thereby established. In any event, the language of the Judiciary Act does not clearly mean "either one or the other, but not both." It could as easily mean "either one or the other or both." Should the former interpretation continue to prevail, however, practical problems in administering the either-or standard will overwlielm self-representation.

understand how the petitioner cau submit the bald proposition that to compel a defendant in a criminal case to undergo a jury trial against his will is contrary to his right to a fair trial or to due process. A defendant's only constitutional right concerning the method of trial is to an impartial trial by jury. We find no constitutional impediment to conditioning a waiver of this right on the consent of the prosecuting attorney and the trial judge when, if either refuses to consent, the result is simply that the defendant is subject to an impartial trial by jury-the very thimg that the Constitution guarantees him.

380 U.S. at 36.

63. FED. R. CRIM. P. 44 [see note 22 supra].

64. 380 U.S. at $34-35$.

65. Id. at 36 .

66. Adams v. Umited States ex rel. McCann, 317 U.S. 269, 279 (1942), citing Johnson v. Zerbst, 304 U.S. 458, 468-69 (1938). See also Moore v. Michigan, 355 U.S. 155 (1957); Carter v. Illinois, 329 U.S. 173 (1946).

67. See text accompanying notes 50-56 supra.

68. United States v. Plattner, 330 F.2d 271, 275 (2d Cir. 1964). 


\section{B. Waiver of Counsel as an Obstacle to Self-Representation}

\section{Competence and Waiver}

Should the Court determine that self-representation is a constitutional right and at the same time find that its exercise acts as a waiver of any right to counsel, the problen of making a competent waiver of counsel would loom as a major obstacle to self-representation. Although the Plattner court held self-representation to be a constitutional right, it added a proviso that the trial judge "should conduct some sort of imquiry bearing upon the defendant's capacity to make an intelligent choice" between representation by counsel and self-representation. ${ }^{69}$ Plattner does not suggest the criteria by which to test competency of a waiver of counsel. The Supreme Court has, however, established guidelines to determine the competency of a waiver on the basis of a due process standard in cases where the defendant pleads guilty. While waiver of counsel in a guilty-plea situation imvolves more serious immediate consequences for the defendant than going to trial, because of the finality of admitting guilt, ${ }^{70}$ the difficulties of conducting a trial suggest that at least the same level of competence be demonstrated for waiver of trial counsel as for pleading guilty.

In Uveges $v$. Pennsylvania, ${ }^{71}$ the Court reversed the conviction of a 17-year-old boy who was permitted to plead guilty to four counts of burglary without the advice of counsel. The Court held:

Where the gravity of the crime and other factors-such as the age and education of the defendant, the conduct of the court or prosecuting officials, and the complicated nature of the offense charged, and the possible defenses thereto-render criminal proceedings without counsel so apt to result in injustice as to be fundamentally unfair ... the accused must have legal assistance under the [Fourteenth] Amendment whether he pleads guilty or elects to stand trial, whether he requests counsel or not. Only a waiver of counsel, understandably made, justifies trial without counsel. ${ }^{22}$

Other cases cite the defendant's mental illness or retardation, ${ }^{73}$ the extent of his prior experience with criminal proceedings, ${ }^{74}$ and the poten-

69. 330 F.2d at 276.

70. See generally sources cited note 4 supra.

71. 335 U.S. 437 (1948).

72. Id. at 441 (emphasis added). The Court's language with regard to situations in which the defendant elects to stand trial and does not request counsel is dictum.

73. E.g., McNeal v. Culver, 365 U.S. 109 (1961); Massey v. Moore, 348 U.S. 105 (1954).

74. Quicksall v. Michigan, 339 U.S. 660 (1950); Wade v. Mayo, 334 U.S. 672 (1948). 
tial severity of the sentence ${ }^{75}$ as criteria of competence to waive counsel.

The general rule to be drawn from Uveges and other cases $^{76}$ tests the defendant's competence against a standard based on the probability of fundainental unfairness in the absence of counsel. The inherent subjectivity of this standard makes it more desirable that self-representation be recognized as constitutionally grounded. As a purely statutory right, a defendant would have to show that denial of permission to defend pro se was clearly erroneous and prejudicial to the defendant. ${ }^{77}$ Appellate courts are normally reluctant to find an abuse of judicial discretion. This normal reluctance is compounded greatly by the need for a showing of prejudice. As a California court said:

It is difficult for a person trained in the law to conclude that one unschooled in the legal arts is better able to present his defense than could an able counsel. Even were we to concede that the exceptional defendant, unschooled in the broad spectrum of the law, could conduct as able a defense in his own behalf as qualified counsel could do, it nears if not reaches the unimaginable to say that a refusal to permit a lay defendant to proceed in propria persona would have prejudiced him. ${ }^{78}$

Thus, allowing self-representation while denying the assistance of counsel may, in fact, effectively preclude self-representation.

\section{Waiver of the Right to Self-Representation Through Acceptance of Counsel}

United States $v$. Conder ${ }^{79}$ upheld the denial of a defendant's request to enter objections to evidence although he had been granted permission to represent himself pro se. The trial court had appointed counsel to aid the defendant in filing pretrial motions, and appointed counsel had also participated with the attorneys for four other defendants in the selection of a jury. The defendant did not participate personally in the jury selection, but re-asserted his right to represent himself on the second day of trial, just before one of his codefendants was to testify as the prosecution's chief witness. The trial court ruled

75. In Uveges, the charges carried a maximum penalty of 80 years.

76. See cases cited notes 73-74 supra.

77. United States v. Plattner, 330 F.2d 271, 273 (2d Cir. 1964). Furthermore, of course, the right would not be guaranteed in state courts.

78. People v. Ruiz, 263 Cal. App. 2d 216, 226, 69 Cal. Rptr. 473, 479 (2d Dist. 1968) (denial of defendant's requests to represent himself held improper under state and federal constitutions).

79. 423 F.2d 904 (5th Cir. 1970). Five defendants were tried together and convicted of conspiracy to burglarize post offices, burglary of post offices, and interstate transportation of goods stolen from post offices. 
that he could not personally raise objections during the direct examination. The defendant did not renew his request or persist in claiming his right to represent himself at the trial, but he appealed on the ground that the trial court's ruling violated his right to proceed pro se under the sixth amendinent.

The Fifth Circuit explicitly recognized that "the right of a defendant in a criminal case to defend pro se is as clearly established as a criminal defendant's right to counsel."80 The court went on to hold, lowever, that the trial court's ruling was correct, apparently for two independent reasons. First, the court held that the defendant had manifested an intent to be represented by counsel in accepting appointed counsel's lelp during the long pretrial period and in the selection of a jury. ${ }^{81}$ In so doing, the defendant "waived" his acknowledged right to represent himself. In addition, the court noted that the trial involved five defendants, each represented by separate counsel, tried under a 12-count indictment. Under those circumstances, the court held that the trial judge was justified in concluding that defendant's participation "would only serve to confuse an already complicated trial. . . .."82

Conder foreshadows a judicial determination to limit self-representation, even if its constitutional basis is conceded. If the impliedacceptance-of-counsel rationale is adopted by courts generally, defendants seeking to defend themselves without counsel will be less likely to cooperate with attorneys appointed by the court to serve in an advisory or stand-by capacity, thus forcing these defendants into a difficult all-or-nothing decision. Such a development is unlikely to afford the defendant assistance in any meaningful sense, or to promote the reliability of the guilt-determining process. Furthermore, the court's clear interest in maintaining orderly proceedings does not preclude thc exercise of a statutory, much less a constitutional right. The time-consuming nature of trial that meets procedural due process standards represents a conscious choice of adherence to rules that are and appear to be fair over expedience in the determination of guilt or innocence. To deny self-representation because it may take more of the court's time leaves the decision in each judge's absolute discretion. Although Conder purports to recognize the right, its rationale effectively will deny it.

80. Id. at 907.

81. Id. at 908. The Fifth Circuit's opinion indicates that counsel was not appointed until the defendant in question complained of not having the proper books and facilities to prepare pretrial motions. "At the time of the appointment the court again acknowledged Grogan's right to proceed pro se and made it clear that the appointed counsel was not to force himself on Grogan." Id. at 907.

82. 423 F.2d at 908. 


\section{Forfeiture by Disruptive Conduct}

Conder involved no abuse by the defendant of his self-representation. In cases where abuse becomes a potential problem, the trial judge's powers to control the proceedings in his courtroom enable him either to limit or to end the self-representation. Illinois v. Allen ${ }^{83}$ presents an extreme example. Allen was allowed to represent himself, but the court also appointed counsel. During the voir dire examination of jurors, Allen became so frustrated at his inability to phrase questions acceptable to the court that he tore up his attorney's files, threatened the judge, and became boisterous and unruly. ${ }^{84}$ The court thereupon removed Allen from the courtroom and directed the attorney to proceed on his behalf. The Supreme Court of Illinois upheld his conviction, explicitly holding that the right to represent oneself and to be present at trial can be waived by deliberate misconduct. ${ }^{85}$ The United States Supreme Court reviewed only the issue of the defendant's right to be present. The separate but necessarily included issue of self-representation was not argued before the Court. In holding that a defendant can lose lis right to be present at trial if lie conducts himself "in a manner so disorderly, disruptive, and disrespectful of the court that his trial cannot be carried on with him in the courtroom," $" 86$ the Court said:

It is essential to the proper administration of criminal justice that dignity, order and decorum be the hallmarks of all court proceedings in our country. The flagrant disregard in the courtroom of elementary standards of proper conduct should not and cannot be tolerated. We beheve trial judges confronted with disruptive, contumacious, stubbornly defiant defendants inust be given sufficient discretion to meet the circumstances of each case. ${ }^{87}$

Thus the basis for the Allen decision requires that a pro se defendant not be accorded any different treatment with regard to lis conduct in court. ${ }^{88}$

A case like Allen is relatively easy, but one can nnagine situations in which the concept of forfeiture by abuse interferes with the legitimate exercise of the right of self-representation. The threat of being forced to accept representation by counsel and possibly being excluded from the trial, while necessary in extreme cases such as Allen or Mayberry v. Pennsylvania, ${ }^{89}$ may circumscribe a defendant's conduct

83. 397 U.S. 337 (1970).

84. People v. Allen, 37 Ill. 2d 167, 169, 226 N.E.2d 1, 2, cert. denied, 389 U.S. 907 (1967).

85. 37 III. $2 \mathrm{~d}$ at 171,226 N.E.2d at 3 .

86. 397 U.S. at 343.

87. Id.

88. Hazard, Securing Courtroom Decorum, 80 YALE L.J. 433, 437 n.3 (1970).

89. 400 U.S. 455 (1971) (conternpt convictions of criminal defendant who, in 
more than is necessary or desirable. The adversary model demands that each party put his claims as forcefully and effectively as he can, but the line between forceful advocacy and abusive behavior has never been satisfactorily drawn with regard to counsel. If the trial court consents to self-representation reluctantly, defendant's attempts to be justifiably forceful may be limited more than his attorney's would be. A possible solution is to provide the pro se defendant with both the duty of restraint and professional assistance without denying his right to represent himself. ${ }^{90}$ This would best be done by granting self-representation constitutional status, with the Supreme Court recognizing that the sixth amendment guarantees assistance of counsel and giving direction on standards of competence. Until the Court resolves these issues, however, the inconsistent law of the various circuits described above and the state laws described below ${ }^{91}$ provide the only guides.

\section{Availability of the Right: State Courts}

More than 30 state constitutions provide that a criminal defendant has the right to appear (and defend) in person and by counsel. Four others provide that he may appear and defend in person or by counsel. ${ }^{22}$ Hence, self-representation appears to be established as a state, if not a federal, constitutional right.

In practice, however, state courts liave so restricted the right that it becomes as difficult for a state defendant to represent himself as for a federal defendant. In People v. Mattson, ${ }^{93}$ for example, the California supreme court ruled that

despite the constitutional (art. I, sec. 13) and statutory (Pen. Code, sec. 686) provisions that defendant has the right to appear and defend in person and with counsel, defendant is not entitled to have his case presented in court both by himself and by counsel acting at the same time or alternating at defendant's pleasure [citations omitted]. So long as defendant is represented by counsel at the trial, he has no right to be heard by himself ... [citations omitted]; conversely, when defendant has intelligently declined the aid of counsel he has no right to interrupt the trial with a demand for legal

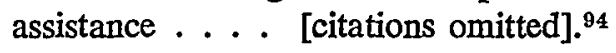

representing himself, repeatedly insulted the trial judge and disrupted the proceedings, reversed because imposed by same judge at conclusion of trial).

90. See text accompanying notes 153-79 infra.

91. See text accompanying notes 92-110 infra.

92. See Brief for the Respondent at 63-67, Gideon v. Cochran [Wainwright], 372 U.S. 335 (1963). See also United States v. Plattner, 330 F.2d 271, 275 nn.6-8 (2d Cir. 1964); W. BeANey, The Right to Counsel in AMrRican Courts 237 (1955).

93. 51 Cal. 2d 777, 336 P.2d 937 (1959).

94. 51 Cal. 2d at 789, 336 P.2d at 946. See also People v. Linden, 52 Cal. 2d 1, 338 P.2d 397, cert. denied, 361 U.S. 867, 969 (1959). 
The court further stated that a defendant for whom counsel is appointed

should not be permitted both to have counsel and to actively participate in the conduct of the case unless the court in its discretion determines that in the circumstances of the case the cause of justice will thereby be served and that the orderly and expeditious conduct of the court's business will not thereby be substantially hindered, hampered or delayed. $\ldots .^{95}$

The reason offered for interpreting "and" to mean "or" advances the interest in the preservation of orderly procedure and decorum. $^{96}$ Thus, orderly proceedings take precedence over the defendant's right to self-representation, since it is within the judge's discretion to decide when self-representation must give way to guarantee order. ${ }^{97}$ This theory acknowledges the conflicting interests of society and the accused involved in a criminal trial, and declares that both can be safeguarded only in an orderly proceeding. Consequently, the judge must have the power to prevent the judicial process from deteriorating because of the accused's inept or disruptive conduct of the defense. ${ }^{98} \mathrm{Al}-$ though the accused has rights of constitutional stature, none is more important to him and to society than the right to a fair, orderly trial.

Implementation of this theory takes the form of limitations on self-representation analogous to those in the federal system. The defendant's competence to waive counsel is a federal constitutional issue, whether the trial be in state or federal court. ${ }^{92}$ Consequently, the same kinds of questions must be asked by state and federal judges to determine whether a knowing and intelligent waiver of counsel exists. ${ }^{100}$

95. $51 \mathrm{Cal} .2 \mathrm{~d}$ at 782, $336 \mathrm{P} .2 \mathrm{~d}$ at 941 . See also $23 \mathrm{C}$.J.S. Right to Appear and Defend in Person $\$$ 979(4), at nn. 98.77-98.83 (1961, Supp. 1971), and cases cited therein.

96. $51 \mathrm{Cal} .2 \mathrm{~d}$ at 787 n.3, 336 P.2d at 945 n.3.

97. See also State v. Martin, 102 Ariz. 142, 145, 426 P.2d 639, 643 (1967); Cappetta v. State, 204 So. 2d 913, 918 (Fla. Dist. Ct. App. 1967); People v. Burson, 11 Ill. 2d $360,373,143$ N.E.2d 239, 247 (1957); State v. White, 86 N.J. Super. 410, 418, 207 A.2d 178, 183 (1965); McCann v. Maxwell, 174 Ohio St. 282, 285, 189 N.E.2d 143, 145 (1963); Annot., 77 A.L.R.2d 1233 (1961).

98. See cases cited note 97 supra.

99. Gideon v. Wainwright, 372 U.S. $335,342-43$ (1963).

100. See People v. Mattson, 51 Cal. 2d 777, 788-89, 336 P.2d 937, 946 (1959); Cappetta v. State, 204 So. 2d 913, 918 (Fla. Dist. Ct. App. 1967); State v. White, 86 N.J. Super. 410, 418, 207 A.2d 178, 183 (1965); McCann v. Maxwell, 174 Ohio St. 282, 285, 189 N.E.2d 143, 145 (1963). See also text accompanying notes 78-85 supra.

People v. Floyd, 1 Cal. 3d 694, 464 P.2d 64, 83 Cal. Rptr. 608 (1970), is illustrative of the factors considered important in determining competence to represent oneself:

The record makes clear that by May 22, when the motion was made, the court had adequate opportunity to observe and listen to Milton, and adeqnate grounds to decide that he could not intelligently waive the right to connsel nor represent himself.

First, the charges against Milton were serious, murder and robbery, with the prosecution seeking the death penalty. Second, the court had been re- 
Where a defendant is deemed competent to represent himself, he is not entitled to privileges or indulgences other than those enjoyed by counsel or by defendants represented by counsel. He may not, for example, rely on the court to serve as his de facto counsel. ${ }^{101}$ Nor may he abuse the patience of the court by demanding an explanation for each ruling. ${ }^{102} \mathrm{He}$ is, however, entitled to the rights ordinarily accorded a defendant, and to some of the privileges of counsel. ${ }^{103}$ Limitations on freedom to move about the courtroom not ordinarily applied to counsel are within the court's discretion. ${ }^{104}$ Access to legal materials is similarly a matter of discretion; no greater access need be granted than to any other defendant. ${ }^{105}$

quested to appoint a psychiatrist to examine Milton, and a plea of not guilty by reason of insanity, although later withdrawn, had been entered. Third, Milton was only 21 years of age at the time of trial, had no prior adult record of convictions, and had a 10th or 11 th grade education.

Moreover, Milton's conduct in court after the court denied his motion to proceed in propria persona makes clear that he was incapable of defending himself. ...

Id. at 704, 464 P.2d at 69, 83 Cal. Rptr. at 613 . No attempt was made to establish a formula using these criteria to determine whether or not a defendant can represent himself. In the final analysis, the defendant's conduct during the pretrial proceedings is probably the only accurate guide, but an evaluation based upon the quality of his presentations and demeanor should be based on how the defendant conducts himself while exercising the right, not after it is denied as in Floyd. See the discussion of Ruchell Magee in text accompanying notes 117-19 infra. See also Manson v. Pitchess, 317 F. Supp. 816 (C.D. Cal. 1970); Seale v. Hoffman, 306 F. Supp. 330 (N.D. Ill. 1969). In any case, legal skills are not a determmative part of the test. As one court said, "if it were necessary for a defendant to satisfy such a test before being permitted to waive counsel, precious little would remain of the constitutional right to defend oneself . . . " State v. Martin, 102 Ariz. 142, 146 n.3, 426 P.2d 639, 643 n.3 (1967); accord, People v. Linden, 52 Cal. 2d 1, 18, 338 P.2d 397, 404-05 (1959); People v. Johnson, 271 Cal. App. 2d 616, 626, 76 Cal. Rptr. 768, 774-75 (2d Dist. 1969); People v. Ruiz, 263 Cal. App. 2d 216, 223, 69 Cal. Rptr. 473, 477 (2d Dist. 1968); People v. Addison, 256 Cal. App. 2d 18, 24-25, 63 Cal. Rptr. 626, 629-30 (2d Dist. 1967). See also Hodge v. United States, 414 F.2d 1040, 1053 (9th Cir. 1969).

101. See, e.g., Pcople v. Jones, 195 Cal. App. 2d 449, 451, 15 Cal. Rptr. 689, 690 (1st Dist. 1961); People v. Morgan, $140 \mathrm{Cal}$. App. 2d 796, 803, 296 P.2d 75, 79-80 (2d Dist. 1956); Gangloff v. State, 232 Miss. 395, 399-400, 99 So. 2d 461, 464 (1958); State v. Miller, 292 S.W. 440, 442 (Mo. 1927).

But see Grubbs v. State, -Ind. -, 265 N.E.2d 40, $43-44$ (1970), where the Indiana supreme court reversed the conviction of an unrepresented accused thief:

The trial court should not permit the prosecutor to ignore the settled rules of evidence. It would not be consistent with our goal of administering the criminal law fairly for the prosecutor to be permitted to secure the conviction of an accused by the use of tactics which prevent the achievement of a fair and just decision.

102. People v. Lamb, 133 Cal. App. 2d 179, 185, 283 P.2d 727, 731 (2d Dist. 1955), cert. denied, 350 U.S. 941 (1956).

103. People v. Maddox, 67 Cal. 2d 647, 653, 433 P.2d 163, 167, 63 Cal. Rptr. 371, 375 (1967). See 23 C.J.S. Right to Appear and Defend in Person $\$$ 979(4), at nn.98.72-98.76 (1961, Supp. 1971) and cases cited therein.

104. People v. Chessman, 38 Cal. 2d 166, 176, 238 P.2d 1001, 1007 (1951).

105. Id. at 173, 238 P.2d at 1005-06. See also People v. Maddox, 67 Cal. 2d 647, 
The most fundamental limitation requires the accused to choose between self-representation and representation by counsel at the outset of the proceedings. ${ }^{100}$ This election is required despite state constitutional provisions that a defendant has a right to represent himself personally, by counsel, or both. ${ }^{107}$ In practice, however, some courts do allow pro se defendants to employ counsel to sit by and advise them during trial, ${ }^{108}$ and with increasing frequency appoint counsel to serve a similar advisory role. ${ }^{109}$ As in the federal courts, however, the practice of appointing or allowing advisory counsel remains completely within the discretion of the trial court. ${ }^{110}$ Thus, despite many clear state constitutional provisions providing for self-representation-often with the assistance of counsel-its status as a right is not significantly different in the state courts than it is in the federal courts.

\section{The Possibility of Abuse}

Trial judges may suspect that those who want to represent themselves simply hope to delay the final outcome of their trials and perhaps discredit the court as well; they may think so regardless of the defendants' tactical, personal, or political motives or the legal right to self-representation. Judges may fear that political defendants hope to make a mockery of justice by raising issues irrelevant to the trial and by using their trials to publicize imsults against the legal system. Some judges also believe that ordinary defendants may try to prevent the trial from opening, by alternately claiming the right to counsel and the right to defend pro se, hoping that each change of mind will result im a contimuance. ${ }^{111}$ Others may attempt to disrupt the proceedings by first representing themselves, then claiming the

654-55, 433 P.2d 163, 167-68, 63 Cal. Rptr. 371, 375-76 (1967); People v. Carter, 66 Cal. 2d 666, 671-72, 427 P.2d 214, 219, 58 Cal. Rptr. 614, 619 (1967); Ligda v. Superior Court, 5 Cal. App. 3d 811, 818, 85 Cal. Rptr. 744, 748 (1st Dist. 1970). But see People v. Martin, 84 Ill. App. 2d 117, 123, 228 N.E.2d 557, 560 (1967).

106. People v. Mattson, 51 Cal. 2d 777, 793-94, 336 P.2d 937, 949 (1959); People v. Ephriam, 411 Ill. 118, 122-23, 103 N.E.2d 363, 365-66, cert. denied, 343 U.S. 930 (1952); People v. Jones, 11 Mich. App. 703, 704, 162 N.W.2d 152, 153 (1968); State v. Sinclair, 49 N.J. 525, 552, 231 A.2d 565, 579 (1967); Application of Trevithick, 81 S.D. 121, 127, 131 N.W.2d 440, 443 (1964).

107. See text accompanying note 92 supra.

108. See, e.g., People v. Mattson, 51 Cal. 2d 777, 797, 336 P.2d 937, 951-52 (1959).

109. See, e.g., Illinois v. Allen, 397 U.S. 337, 339 (1970), quoting Umited States ex rel. Allen v. Illmois, 413 F.2d 232, 233 (7th Cir. 1969). See also Mayberry v. Pennsylvamia, 400 U.S. 455, 466-68 (1971) (Burger, C.J., concurring) [discussed in text accompanying note 168 infra].

110. People v. Mattson, 51 Cal. 2d 777, 797, 336 P.2d 937, 951-52 (1959).

111. See, e.g., United States v. Birrel, 286 F. Supp. 885, 894-95 (S.D.N.Y. 1968); United States v. Davis, 260 F. Supp. 1009, 1020-22 (E.D. Tenn. 1966); People v. Weston, 9 Cal. App. 3d 330, 334, 87 Cal. Rptr. 922, 924-25 (2d Dist. 1970); State v. White, 86 N.J. Super. 410, 418-19, 207 A.2d 178, 183 (1965). 
right to counsel once trial is under way-again, hoping for a continuance or even a mistrial. ${ }^{112}$ Still others may hope to conduct their defense so poorly that an appellate court will grant a new trial because of inadequate representation. ${ }^{113}$

The possibility of abuse is undoubtedly real in both poitical and nonpolitical cases. Yet, the possibility of determining accurately whether a defendant plans to abuse the right when he initially moves to proceed pro se is extremely slight. Judges' experiences with other pro se defendants, their legal training, and their bureaucratic predispositions lead them to prefer that defendants be represented. ${ }^{114}$ Their first reaction, other things being equal, is to deny such requests through whatever legal means are available. When Bobby Seale or Ruchell Magee is not allowed to exercise what he reasonably believes is a constitutional right, he will protest in "the vigorous speech of the streets, not the accepted courtroom litany." 115 Such speech begins the now-familiar vicious cycle, perhaps leading to the defendant's exclusion from his trial, ${ }^{116}$ and inevitably leaves the judge convinced he was right in the first place. He will be less inclined to allow the next defendant who wants to represent himself to do so, and the defendant will have less reason to beheve he can get a fair trial. The rationale behind the judges' feelings is based upon a number of assumptions about the quality of legal representation available to criminal defendants. The validity of these assumptions becomes less apparent as the reasons why various kinds of people choose to represent themselves are explored.

II

\section{MOTIVATIONS FOR SELF-REPRESENTATION}

Although the demands for self-representation are made most forcefully in the context of modern "political" trials, the issues they raise are common to many criminal trials and can be seen most clearly in a nonpolitical context. The demands for self-repesentation are a challenge to current assumptions about assistance of counsel.

112. See, e.g., People v. Hill, 268 Cal. App. 2d 504, 508, 74 Cal. Rptr. 180, 183 (2d Dist. 1968); People v. Powers, 256 Cal. App. 2d 904, 914, 64 Cal. Rptr. 450, 457 (1st Dist. 1967); State v. Penderville, 2 Utah 2d 281, 287-88, 272 P.2d 195, 199 (1954). See also Laub, supra note 17 , at 249-51.

113. People v. Chessman, 38 Cal. 2d 166, 178, 238 P.2d 1001, 1008 (1951), cert. denied, 343 U.S. 915 (1952).

114. See Laub, supra note 17, at 245: "Most trial judges are in agreement with [Gideon], not so much on constitutional grounds but because they see practical advantages therein, and because they would welcome an even broader rule requiring every party to a lawsuit to have full representation."

115. Tigar, supra note 4 , at 27.

116. See, e.g., Mayberry v. Pennsylvania, 400 U.S. 455 (1971); Illinois v. Allen, 397 U.S. 337 (1970); Seale v. Hoffman, 306 F. Supp. 330 (N.D. Ill. 1969). 


\section{A. Distrust of the Legal System}

The courts are faced with an increasing number of black defendants who previously have not been politically active, but who refuse to accept court-appoimted counsel or public defenders as their attorneys. Ruchell Magee's demand for self-representation is a good example; it is based on distrust borne of experience:

[E]very California lawyer that I have had has convicted me through fraud, known to be such .... [ [F]or over seven years $I$ have been forced to stay in slavery on fraud [sic] pleas of guilty, made by attorneys, court-appointed attorneys over iny objection, over my plea of not guilty, and over my testimony of not guilty. ${ }^{117}$

Magee is not unique. In one issue the San Francisco Chronicle reported two similar stories: Raymond Lee Scott, accused of two murders, punched a deputy public defender because "ine and the Public Defender's office are im direct conflict," right to defend himself. The "Soledad Three" and three other Soledad Prison inmates accused of murdering a guard refused for a time to accept or talk with their court-appointed lawyers. ${ }^{119}$

If Magee's demand for self-representation arises froin mistrust of the entire judicial system, Bobby Seale's motive for demanding self-

117. Davis Transcript 33-34 (May 5, 1971). Magee also stated:

I cannot accept an attorney, an attorney appointed by no state judge nor federal judge at this particular time due to the fact that I'm aware, and fully aware of a conspiracy that exists from President Nixon down to prison guards in this case, out to hide and conceal evidence in this case, evidence that will prove and show that the entire State of California, the American judicial systein, prison system, is practicing slavery under the color of law, without legal power or authority. One would have to be very naive to believe that any court could-permitting such acts would appoint one attorney to whip theinselves, or expose theinselves. This is the reason that I constantly refused attorneys, and I have explained this to thein.

Id. at 41-42. Magee's accusations are difficult to accept for anyone unfamiliar with his case, but the basis for his distrust is not as ridiculous as it may seem. Magee has argued for Inore than six years while in prison, and throughout the 12 months of pretrial proceedings, that his 1965 robbery conviction was procured through the inadequate, if not improper, behavior of the appointed counsel at his trial. He has repeatedly requested that the records of that trial be subpoenaed in order to challenge the legality of his confinement in San Quentin on August 7, 1970, and thereby lay a foundation by which the charge of assault with a deadly weapon while a prison inmate under a life sentence, which carries a mandatory death penalty [CAL. PENAL CODE $\$ 4500$ (West 1970)], can be dismissed. Davis Transcript 33-34 (May 5, 1971). Ernest L. Graves, who was appointed by the court to protect Magee's interests on May 5, 1971, obtained the records of the Los Angeles trial, something none of Magee's prior appointed counsel had done. On October 15, 1971, he argued once again that a hearing should be set to determine the legality of Magee's confinement, supporting his motion with portions of the 1965 trial transcript. The court found enough substance in Magee's charges to order the long-requested hearing be set for November 10, 1971. S.F. Chronicle, Oct. 16,1971 , § 1 , at 5 , col. 1 .

118. S.F. Chronicle, Nov. 11, 1970, § 1, at 2, col. 2.

119. Id. $\S 1$, at 2 , col. 4 . 
representation at the Chicago conspiracy trial derives from a willingness to trust only one attorney-Charles Garry. Seale's abortive efforts are important because they question the assumption that all attorneys, even "Movement" attorneys have the same competence and political commitment. Seale had no thought of representing himself until the court refused to allow a seven-week delay in opening the trial to enable his attorney to recover from an operation. ${ }^{120}$ William Kunstler, attorney for the other defendants, filed an appearance on behalf of Seale two days before the trial opened, solely to obtain permission to visit him in jail. The two had never met; Seale had not talked with counsel since his abrupt departure from California. ${ }^{121}$

Seale refused to accept Kunstler as his attorney, but the court would not allow him to fire Kunstler or allow Kunstler to withdraw. ${ }^{122}$ Whatever the significance of Kunstler's subsequent work in Chicago, Seale simply did not know or trust him at the outset. Garry was the Panthers' lawyer. He had taken great care to understand their political philosophy and had the necessary background to discover prejudices in potential jurors, and to counter the nuances of prosecution testimony about Seale's state of mind in coming to Chicago. Most important, he had proven that he was an effective trial lawyer. ${ }^{123}$ Seale perceived differences not so much between Garry and Kunstler as between Garry and any other attorney. Rather than gamble with an unknown, he chose to rely on himself. ${ }^{124}$

120. Waltz, Foreword to The Supreme Court Review 1970, 61 J. CRM. L.C. \& P.S. 484, 488 (1970). See also Playboy Interview: William Kunstler, 17 PLAYBoY 71, 76 (Oct. 1970).

121. The Tales of Hoffman 10 (M.L. Levine, G.C. McNamee \& D. Greenberg eds. 1970) (an edited transcript of United States v. Dellinger, No. 69 Crim. 180 (N.D. III. Mar. 20, 1969) ) [hereinafter cited as THE TALES OF HOFFMAN].

122. Seale first tried to fire Kunstler on Sept. 26, 1969, five days after the trial had formally commenced, but either before the final jury selection [14 Civ. Lib. Dock. 92 (1970)] or before the jury heard any evidence [CONTEMPT, TRANSCRIPT OF THE Contempt Cttations, Sentences, and Responses of the Chicago Conspiracy 10, at 4-5 (D. Wagner and M.P. Weisman eds. 1970) [hereinafter cited as CoNTEMPT]]:

"MR. SEALE: Hey, you don't speak for me. I would like to speak on behalf of my own self and have my counsel handle my case in belhalf of myself. How come I can't speak in belalf of myself? [I don't want these] lawyers to represent me.

"THE COURT: You have a lawyer of record, and he has been of record here for you since September 24.

"MR. SEALE: I have been arguing that before that jury heard one shread of evidence. I don't want these lawyers because I can take up my own legal defense, and my lawyer is Charles Garry."

123. Shortly before the Chicago case he had won an outright acquittal for the "Oakland Seven," and saved Panther Huey Newton from California's death row. See C. Rosebury, Black Liberation on Trial (1968) (a pamphlet reprimted from articles appearing in The People's World in the summer of 1968).

124. Despite Seale's repeated demands, the court refused to allow him to participate in jury selection, opening statements, or cross-examination of prosecution witnesses. 
The reaction of many criminal defendants, black or white, whether politically militant or not, who must rely on a public defender or any unknown lawyer, is likely to be distrustful, especially if the defendant is innocent. The bureaucratic and economic pressures that produce a guilty-plea rate of about 90 percent $t^{125}$ manifest themselves clearly to a defendant who does not even know the name of his lawyer, and probably vice versa, at arraignment. The strong imstitutional pressures on defense lawyers, whether publicly or privately paid, to cooperate with the prosecutor and the court in processing large numbers of cases, thereby compromising, or appearing to compromise, their role as advocates, ${ }^{126}$ have become common knowledge. ${ }^{127}$ In Moore v. United States, ${ }^{128}$ the Third Circuit recognized that in the mechanics of such institutionalized systems as the public defender's office

there are inherent the risks of a loss of the close confidential relationship between litigant and counsel and the subordination of an individual client's interest to the larger interest of the organization. These risks of course are greater in the case of indigents for whose clientele there is no compensating pressure of competition. ${ }^{129}$

The poor or minority defendant's sense of being an outsider whose interests are not foremost in his attorney's mind does not necessarily support his conclusion that he cannot expect competent representation at trial. ${ }^{130}$ The professionals of the criminal justice system probably

Seale persisted in his demands through the sixth week of trial, when the court summarily sentenced him to four years imprisonment on 16 separate contempt specifications and severed his case. The TALEs of HoffMan 72-74; CoNTEMPT 1-37.

125. The President's Commission on Law ENForcement and Administration OF JUSTICE, TASK Force RePort: The COURTS 9 (1967).

126. See Blumberg, The Practice of Law as a Confidence Game: Organizational Cooptation of a Profession, in Crime \& The Legal Process 220-37 (W.J. Chamblis ed. 1969); Skolnick, Social Control in the Adversary System, 11 J. ConfLrct ResoluTION 52-70 (1967).

127. See, e.g., Goldman \& Holt, How Justice Works: The People v. Donald Payne, NEWSWEEK, Mar. 8, 1971, at 20, 29:

You learn its folkways. "It's our court," Xinos [a Chicago public defender] says. "It's like a family. Me, the prosecutors, the judges, we're all friends. I drink with the prosecutors. I give the jndge a Christmas present, lie gives me a Christmas present."

$$
\text { .... }
$$

That they [the defendants] are all nominally innocent under the law is little more than a technicality: public and private defenders learn quickly to presume guilt in most cases and to work from there.

128. 432 F.2d 730 (3d Cir. 1970).

129. $1 d$. at 736 .

130. In Moore, the court declined to hold that representation by the Defender Association of Philadelphia, which began at arraignment, was per se inadequate even though the attorney who represented the defendant at trial did not meet the defendant until the day hefore trial. The court did, however, order that an evidentiary hearing be held on the issue of ineffective representation. 432 F.2d at 739-40. Cf. Grano, The Right to Counsel, 54 MnN. L. REv. 1175, 1197-98 (1970). 
conform more closely to the adversary model in the small percentage of cases that are tried. The average defendant, however, whose only previous experience has been with the guilty-plea process, has no way of knowing or believing this. He may well believe that, given the level of individual attention he has received in the past, he is better off representing limself. If he runs a higher risk of conviction and a stiffer sentence, he will at least have the satisfaction of not being "burned" by a lawyer whose primary commitment seeined to be processing a large number of cases without giving significant attention to any one. ${ }^{131}$

Sucli defendants also raise the issue of who is competent to represent himself. If their crimes are the product of poverty, they are unlikely to have had sufficient formal education to enable them to verbalize their thoughts in court. Their knowledge of law and procedure derives primarily from prior experiences in court, perhaps supplemented by studies in a prison library. ${ }^{132}$ If these kinds of defendants want to represent themselves, as some do, the court must take measures to ensure that the proceedings meet the requirements of due process. However, these measures need not completely preclude selfrepresentation in all cases; a rational approach will admit that a counsel-assisted form of self-representation is possible. ${ }^{133}$

\section{B. Political Considerations}

Events of the 1960 's, especially as interpreted by some blacks, students, and antiwar militants, led to an mcreasing number of criminal trials with political backgrounds, overtones, or consequences. ${ }^{134}$

131. See text accompanying note 33 supra. For examples of cases where defendants claimed to be "burned" by appointed counsel or public defenders, see People v. Mattson, 51 Cal. 2d 777, 336 P.2d 937 (1969); People v. Hill, 268 Cal. App. 2d 504, 74 Cal. Rptr. 180 (2d Dist. 1968); People v. Powers, 256 Cal. App. 2d 904, 64 Cal. Rptr. 450 (1st Dist. 1967).

132. See the discussion of Illinois v. Allen, 397 U.S. 337 (1970), in text accompanying notes 83-88 supra.

133. An alternative to the all-or-nothing approach to self-representation is discussed in text accompanying notes 153-79 infra.

134. There is no sure formula for telling whether a trial is political. Such variables as the defendant's alleged criminal actions, his statements prior to trial, and his conduct during the trial, may all tend to measure the political importance of a case. Public references by the prosecutor to such things as the defendant's alleged ideological motivation, or attempts to prove such motivation at trial, may point up the political clement of the case. Apart from, or because of, the wishes of the active participants, the quantity and tone of press coverage may build upon any political overtones in a case, converting a somewhat ordinary trial into a pohtical incident.

Despite these and other complexities it is possible to identify certain trials and defendants as "political." The trials of Jesus and Socrates were among the earliest and most famous of the poitical variety. O. KIRCHHEIMER, Political JUSTICE 225-29 (1961). Moreover, these defendants argued their cases themselves. 17th-century England experienced the trials of Sir Walter Raleigh for treason [C. BowEN, THE 
In some of these trials, defendants have decided to press for self-representation, or an unusual form of the lawyer-client relation. The reasons these defendants seek to represent themselves are comprehensible only in the context of their particular circumstances. Courts should not assume that all so-called "political" defendants are seeking to use their trials as forums for political propaganda. To Bobby Seale and Angela Davis, for example, the political consequences of self-representation are not as significant as the legal consequences: they seek to effect an acquittal. ${ }^{135}$

Others have sought to represent theinselves primarily to maintain the integrity of their political and moral commitments; ${ }^{136}$ it does not follow, however, that their political views are always irrelevant to their trials. Such is the case of the "Milwaukee Twelve," a group of Catholic clergy, Christian Brothers, and laymen tried in Wisconsin on charges of burglary, arson, and theft arising from their destruction of selective service records. ${ }^{137}$ The Twelve dismissed a teain of civil liberties lawyers just before trial in the hope that, acting as their own counsel, they could interpose the moral justifications for their acts as a defense. They sought to demonstrate through imtelligent, articulate courtroom conduct that their beliefs deserved consideration. ${ }^{138}$

The Twelve did not contest the material elements of their offenses. Throughout the trial, they were unusually successful in introducing evidence about the Vietnam War and their personal beliefs without violent disruptions or confrontations with the prosecutor or the

LION AND THE THRONe 190-224 (1956)] and William Penn for inciting a riot by preaching in Grace Church Street without a permit [The Trial of William Penn, 6 How. St. Tr. 951 (1670), cited in Illinois v. Allen, 397 U.S. 337, 351, 353 (1970) (Douglas, J., concurring)]. In 20th-century America, Clarence Darrow's closing arguments refuting charges of attempted jury tampering in the McNamara-L.A. Times labor case [C. Darrow, The Story OF MY LIFE 186-89 (1932); C. Darrow, AtTorney For the DAMNED 494-531 (A. Weinberg ed. 1957)] and Eugene Dennis' pro se defense in the Sinith Act trial of 1949 [Dennis v. United States, 341 U.S. 494 (1950); see O. KIRcHHEIMER, supra at 136,139,143-44, 147] stand out as illustrations of self-representation in political trials.

135. See text accompanying notes 120-24 supra, 148-52 infra.

136. One statement of this kind of political approach appears in T. HAYDEN, Trial 99 (1970):

We cannot resist illegitinate authority in the streets only to bow politely before it in the courtroom. We have to nake clear in court that it is our identity, our politics, and our life style that the government is attacking. We have to appeal to the jury outside and inside the court, to accept our pohtics as legitimate. Without risking needless time in jail, we nust risk 'contempt of court' when the court is brazenly in contempt of our rights. We should experiment with acting as our own lawyers as a way to place our identity directly before the jury and the larger public.

137. See Gray, The Ultra-Resistance, in Trials of the Resistance 125, 130 (1970) (essays collected from THE NEW YoRk REVIEW of Books).

138. Gray, supra note 137 , at 138-39, 145-46. 
judge. Although convicted, they received relatively mild two-year sentences. ${ }^{139}$

The Twelve demonstrated that self-representation in a political trial can meet the requirements of due process. The trial was orderly and relatively expeditious. Despite the large number of defendants with acknowledged political aims in conducting their trial, both the defense and prosecution ably presented their cases to the jury. ${ }^{140}$

The trial of the Twelve also slowed that laymen can achieve a favorable result im a political case by personally interacting with the judge, jury, and prosecutor. In so doing, they questioned one basis for professional representation: that an attorney is better able to articulate the defendant's position than the defendant himself. However complex the procedures of a criminal trial, the complexities of the outside world that motivate the defendant to behave criminally may be far more difficult to understand and explain. In political cases where the defense is primarily moral, rather than legal, the defendant can express his justifications as well or better than the attorney.

\section{Tactical Advantages}

Some defendants, who may or may not be able to find a lawyer they trust, occasionally see tactical advantages in representing themselves. Caryl Chessman, for example, sought to convey the impression that lie was "a blundering person rather than a clever professional" in his trial for 17 felony offenses, including three counts of kidnapping with the purpose of robbery and infliction of bodily harm. ${ }^{141}$ Although Chessman failed, the concept of a defendant doing something unusual to win the jury's sympathy is inescapably a part of jury trials. A jury does not base its finding solely on proper testimony and evidence; the defendant's dress, mannerisms, and speech all become part of the jury's deliberations. ${ }^{142}$ If he can convey an impression of him-

139. Id. at 154. The federal government subsequently indicted 11 of the Twelve for conspiring to destroy government records and for obstructing the Selective Service System. The indictment was dismissed, however, because prejudicial publicity made a fair trial impossible in the Eastern District of Wisconsin, and the defendants refused to waive their right to be tried in that district. Uuited States v. Cotton, No. 68CR-113 (E.D. Wis., filed Oct. 17, 1968); 14 Crv. Lib. Dock. 87 (1970). The Supreme Court dismissed the government's appeal per curiam on Feb. 24, 1970. 397 U.S. 45 (1970).

140. Gray, supra note 137 , at 154 .

141. See People v. Chessman, 38 Cal. 2d 166, 178, 238 P.2d 1001 (1951), cert. denied, 343 U.S. 915 (1952).

142. See Schur, Scientific Method and the Criminal-Trial Decision, 25 SocinL RESEARCH 173, 180 (Summer 1958) ("In all this it is evident that the decision of the "trier of fact' (and this is particularly true in the jury trial) tends to be a gestalt response to the case and trial as a whole"). Yet, in The American Jury, Kalven and Zeisel show that 
self as a basically good person or as a blundering individual fighting alone against the power of the state, he may be able to win enough sympathy to avoid a death sentence, as Chessman tried to do, or, in a less serious case, to receive a lighter sentence or even acquittal.

If the defendant does not represent himself, however, his only opportunity to impress the jury, other than sitting mutely at counsel table, is on the witness stand. Testifying may involve putting facts before the jury which they would not otherwise be entitled to know, such as the existence of a previous criminal record, ${ }^{143}$ or a confession elicited in violation of Miranda v. Arizona. ${ }^{144}$ If the jury is able to lear such daunaging evidence, any favorable impression the defendant might otherwise create is destroyed. Self-representation, although not permitting the defendant to make unsupported factual statennents free froin cross-examination, does allow him to address the jury personally, to argue whatever facts are independently introduced in his favor, and through his behavior, to give the jury an insight into his character. ${ }^{145}$

In cases where the defendant understands the circumstances of the offense more clearly than a lawyer could, or personally knows the witnesses, he may be able to conduct parts of his trial more effectively than a moderately prepared lawyer ${ }^{146}$ One court acknowledged that in cases where the attorney has not prepared fully, "a defendant who knows the facts of his case may indeed be better off defending himself without an attorney . . ."147 Under these circum-

whatever the individual differences were among almost two-thirds of criminal defendants, they made no impression on the jury. In only 19 percent of the cases studied was the jury's decision influenced by sympathy for the defendant. Self-representation is a dramatic tactic that may improve the defendant's chances of obtaining sympathy. See $\mathrm{H}$. Kalven, JR. \& H. Zeisel, The AMERICAN JuRy 214 (Table 67) (1966).

143. "The accused, as a witness, is open to impeachment as to character, by crossexamination or otherwise, like any other witness." $8 \mathrm{~J}$. WIGMORE, EVIDENCE $\$ 2277$ (McNaughton rev. 1961).

144. 384 U.S. 436 (1966). Such a confession is admissible to impeach a defendant's statements made as a witness. Harris v. New York, 401 U.S. 222 (1971).

145. It is true that the Constitution may not guarantee a defendant the use of such methods of persuasion, but objections to these kinds of tactical advantages derive not from their use by a pro se defendant, but from their apparent deviance from the truthfinding norm. As such, they are neither more nor less justified than the analogous devices employed by attorneys. In any event, they are presented here to help demonstrate why a defendant who is interested in winning his case may choose to represent himself.

146. See, e.g., United States v. Abbamonte, 348 F.2d 700, 704 (2d Cir. 1965); United States v. Private Brands, Inc., 250 F.2d 554, 556 (2d Cir. 1957).

147. United States ex rel. Davis v. McMann, 386 F.2d 611, 620 (2d Cir. 1967), cert. denied, 390 U.S. 958 (1968). See also Anderson v. Commonwealth, 353 S.W.2d 381, 385 (Ky. App. 1962), cert. granted, 371 U.S. 886 (1962), motion for hearing denied, 379 U.S. 805 (1964):

The defense of conspiracy [involving defendant's former employer, newspapers, and various public officials] unquestionably could not have been presented 
stances both the defendant's interest in averting a verdict of guilty or a long sentence and society's interest in discovering the truth may be injured by forcing counsel on the defendant.

Angela Davis' reasons for acting as co-counsel derive more from this kind of pragmatism than from politics. Her alleged criminal actions consist of furnishing the weapons used by Jonathon Jackson in his attempt to help black San Quentin Prison inmates escape from the Marin County Civic Center. ${ }^{148}$ Although the events of August 7, 1970 , are not without political significance, they were probably not intended simply as political statements. The seriousness of the capital charges takes them well beyond the scope of relatively peaceful acts of civil disobedience or resistance. Unlike the Twelve, her reasons for wanting to participate do not include a desire to stress a moral justification for the alleged acts; rather, she wants to participate both because her political beliefs compel her to play an active role, rather than sit quietly while-her attorneys defend her, and because she believes that she alone is best qualified to refute anticipated prosecution testimony about her political beliefs and activities. Her argument for cocounsel status makes this clear:

I have been charged with three capital offenses, murder, kidnapping, conspiracy, and my life is at stake in this case . . not simply . . . the life of a lone individual, but, rather, . . . a life which has been given over to the struggles of black people . . . . I don't think that I should be forced to remain mute, [a] face behind counsel table, an abstraction. I should be able to do precisely the kind of things that would tend to allow us to put forth the most efficacious type defense, and I am not talking about trying to create a political forum in this courtroom; I am not talking about making irrelevant political remarks; I'm talking about being able to make arguments, being able to make motions, objections, and being able to examine witnesses when it becomes clear that I am the nost competent person in the legal team to do so. ${ }^{149}$

The Angela Davis trial challenges the traditional assumption that all defendants are the same in the eyes of the law, and, consequently, that only one attorney-client model is appropriate. As a well-educated, articulate person, she, like the Twelve, has the intellectual and verbal abilities to speak on her own behalf. That she also wants to have the assistance of professional counsel during portions of the

with sincerity by counsel. Actually, by reason of his belief in it, Anderson was best qualified to present this defense himself.

148. For a detailed description of the events of August 7, 1970, and of the publiclyknown evidence against Angela Davis, see Skolnick \& Brick, A Fair Trial for Angela Davis?, 213 The Nation 46-50 (July 19, 1971); 18 NEW SocieTY 100-04 (July 15, 1971).

149. Davis Transcript $39-40$ (July 21,1971 ). 
proceedings indicates that she recognizes that the case is too complex to handle alone. ${ }^{150}$

In her argument for co-counsel status, Angela Davis questioned the legal basis for requiring a defendant to forgo one important right -assistance of counsel-in order to exercise another-self-representation: "[T]his either/or situation flies in the face of justice, because if one right can be exercised only when the other is renounced, it would appear to ine that these are not rights at all."151

In Angela Davis' case her motion to act as co-counsel was granted without resolving the fundamental issue she raised in oral argument. ${ }^{152}$ Hence, the question remains: in light of the established basis of the right to represent oneself and the conceded benefits of granting all defendants the assistance of counsel, why should a defendant be forced to choose?

\section{III}

\section{An Alternative to the All-OR-Nothing ApProach}

The limitations on the right to defend pro se analyzed in part I may be thought of as implementations of the due process interest in reliability of the guilt-determining process. These restrictions on the defendant's control of his defense make sense only insofar as they guarantee a fair trial for all participants. Yet, the requirement under state $^{153}$ and federal ${ }^{154}$ law that pro se defendants forgo professional legal representation at their trials lessens the probability of attaining a fair trial; the question is whether this deficiency is balanced by the furthering of other societal interests, such as the interest in an orderly trial. In weighing the considerations, proponents of the either-or approach should recognize that the plain language of the sixth amendment's guarantee of assistance, and, more emphatically, the explicit state constitutional guarantees of right to counsel and right to self-representation $^{155}$ do not support an either-or interpretation of these rights. In addition, simultaneous self-representation and assistance of counsel has several practical advantages that should be carefully considered before denying the pro se defendant's request for assistance.

First, if a defendant knows that he will be allowed to participate in his trial to the extent that he slows himself capable of doing so, he is more likely to listen to the advice of a trained attorney, whether from

150. Davis Transcript 42 (July 21, 1971).

151. Id.

152. Davis Transcript 23-24 (July 27, 1971). See text accompanying note 10 supra.

153. See text accompanying note 94 supra.

154. See text accompanying note 46 supra.

155. See note 92 supra. 
the public defender's office, appointed by the court, or retained. The problem of trusting unknown counsel is greatly diminished when the defendant knows that counsel will not have complete control of defense decisions. ${ }^{158}$ Admittedly, this arrangement is only a stop-gap until the quality of the criminal bar is such that a defendant will be able to trust the unknown attorney who announces that he will handle the case. But comprehensive reform, upgrading the quality of the average criminal lawyer, and restructuring the public defender system so that deputies will be able to spend an adequate amount of time on each case, is not and cannot be the responsibility of the defendant. In the meantimie, the adversary model assumes, and the rehability of the guilt-determining system requires, that the defendant will maximize his position before the court. If he can only do so by retaining ultimate control over the conduct of the defense, his individual interests and the interests of society will be better served by allowing counsel to provide what the sixtl amendment calls for-assistance.

Second, appointment of advisory counsel at the outset of the proceedings to help the defendant determine what pretrial motions are appropriate and to give legal advice generally, may enhance the defendant's respect for the judicial system, as long as he can be certam that cooperating with counsel will not be deemed a tacit waiver of his right to represent himiself. ${ }^{157}$ Respect for the system is requisite to the "dignity, order and decorum"158 essential to the proper administration of justice. Although trial courts can expel unruly defendants, ${ }^{160}$ a trial that is and appears to be fundamentally fair is more likely with the defendant present and participating.

Third, although the Supreme Court has recognized that a trial judge "may guide a defendant without a lawyer past the errors that make trials unfair," ${ }^{160}$ the assistance of advisory counsel removes the

156. A difficult question arises when the views of the accused and his counsel differ on a question of strategy. Currently the law of the Ninth Circuit, which is probably representative of inost jurisdictions in this respect, is that counsel's view controls. The court explained its position in this way:

Our reasons are that only counsel is coinpetent to make such a decision, that counsel must be the manager of the law-suit, that if such decisions are to be made by the defendant, he is likely to do himself more harm than good, and that a contrary rule would seriously inpair the constitutional guaranty of the right to counsel. . . . One of the surest ways for counsel to lose a lawsuit is to permit his client to run the trial. We think that few competent counsel would accept retainers, or appointment under the Criminal Justice Act of 1964, to defend criminal cases, if they were to have to consult the defendant, and follow his views, on every issue of trial strategy . . . .

Nelson v. California, 346 F.2d 73, 81 (9th Cir. 1965).

157. See text accounanying notes 79-82 supra.

158. Illinois v. Allen, 397 U.S. 337, 343 (1970).

159. Id.

160. Gibbs v. Burke, 337 U.S. 773, 781 (1949) (guilty-plea conviction reversed on ground that defendant was denied a fair trial). 
court from the difficult position of giving special attention to the rights of one party while acting as an impartial umpire. Under current law, judges are not obligated to give special attention to a pro se defendant, ${ }^{161}$ but in practice they often try to perform some of the functions counsel would ordinarily assume in order to ensure fairness. ${ }^{162}$ As long as the adversary model is retained, this dual posture is untenable.

Finally, the presence of advisory counsel gives the court more flexibility in conducting the proceedings and can save the court from urmecessary delays. Initial determinations that a defendant wants to represent himself solely to disrupt and delay the trial cannot be made accurately, ${ }^{163}$ and run the risk of becoming self-fulfilling prophesies in cases where defendants are determined to exercise their right to represent themselves. But, if the court allows a defendant to represent himself and lie subsequently abuses the right, the proceedings will liave to be stopped to allow an attorney to familiarize himself with the record, unless the attorney lias been present from the beginning of the case.

The problem of determining competence to represent oneself is a similar, if more complex, problem and is susceptible to the same solution. The mitial standard of mental competence to stand trial requires only that a defendant be able to cooperate with counsel in the preparation and presentation of his defense. ${ }^{164}$ The standard for a valid waiver of counsel requires that the waiver be made knowingly and intelligently. ${ }^{165}$ Neither of these standards, lowever difficult to apply in themselves, measures the defendant's mental or intellectual ability to organize, manage, and conduct his defense, or his willingness to present his defense im accordance with procedural rules. ${ }^{166}$ These factors of competence to represent oneself can only be determined with fairness and accuracy by allowing defendants to try self-representation. The court can obviate the problems that would result if the attempt proves abortive by appoimting counsel at the outset.

The force of this analysis was tacitly recognized by Chief Justice Burger in Mayberry v. Pennsylvania. ${ }^{167}$ The Chief Justice addressed

161. See text accompanying note 101 supra.

162. Grubbs v. State, - Ind. - 265 N.E.2d 40, $43-44$ (1970).

163. See text accompanying notes 114-16 supra.

164. See, e.g., People v. Wolff, 61 Cal. 2d 795, 799, 394 P.2d 959, 961, 40 Cal. Rptr. 271, 273 (1964).

165. Adams v. United States ex rel. McCann, 317 U.S. 269, 279 (1942).

166. In United States v. Odom, 423 F.2d 875 (9th Cir. 1970), Judge Hufstedler noted that the standards for competency to stand trial, to waive counsel, and to represent oneself "present an extremely difficult problem" but did not attempt to resolve it since she was satisfied that the defendant "met even the most elevated of these standards." Id. at 877 (Hufstedler, J., concurring). Cf. Note, 49 MiNN. L. Rev. 1133, 1141-46 (1965).

167. 400 U.S. $455,466-68$ (1971) (Burger, C.J., concurring). 
himself more to the rights of the trial judge than to those of the defendant in declaring:

When a defendant refuses counsel, as he did here, or seeks to discharge him, a trial judge is well advised-as so many do-to have such "standby counsel" to perform all the services a trained advocate would perform ordinarily by examination and cross-exammation of witnesses, objecting to evidence and making closing argument. No circumstance that comes to mind allows an accused to interfere with the absolute right of a trial judge to have such "standby counsel" to protect the rights of accused persons "foolishly trying to defend themselves" . . . .168

As the Chief Justice indicates, the appointment of standby counsel for pro se defendants is a fairly common practice. ${ }^{100}$ Yet, it is a practice that remains within the court's discretion under state and federal law, apparently for two reasons. First, the courts seem to feel that allowing a pro se defendant to have advisory counsel would be more disruptive of the proceedings-causing delays, creating opportunities for improper behavior, and generally adding confusion. ${ }^{170}$ The logic of this objection extends to all forms of defendant participation, however, and not only to the question of advisory counsel. Presence of such counsel, as suggested above, would probably limit, rather than exacerbate, such problems. And, in view of the common practice of appointing such counsel whether the defendant requests assistance or not, ${ }^{171}$ this explanation is not persuasive.

The second rationale is that the courts do not want to force attorneys to "surrender any of the substantial prerogatives traditionally or by statute attached to [their] office"172 or force them to "occupy an inferior position ...."173 This rationale may have some merit in the rare case where an attorney is appointed to represent a client against the attorney's will, or the more frequent case where a public defender's office is called upon to provide assistance; ${ }^{174}$ it has no

168. Id. at 467-68. The Chief Justice's solution is an important step towards reconciling the two due process interests involved in pro se representation. In forcing standby counsel on an unwilling defendant, however, the court is imposing a compromise that may prove unacceptable to some defendants, particularly those who wish to raise only moral and political defenses to the charges.

169. Id. at 467.

170. See, e.g., United States v. Conder, 423 F.2d 904, 908 (6th Cir. 1970); People v. Mattson, 51 Cal. 2d 777, 782, 792-93, 336 P.2d 937, 941, 948-49 (1959).

171. Mayberry v. Pennsylvania, 400 U.S. 455, 466, 467-68 (1971) (Burger, C.J., concurring).

172. People v. Mattson, 51 Cal. 2d 777, 336 P.2d 937, 941 (1959).

173. Shelton v. United States, 205 F.2d 806, 813 (5th Cir.), petition for cert. dismissed on petitioner's motion, 346 U.S. 892 (1953), motion to vacate denied, 349 U.S. 943 (1955).

174. See, e.g., Ligda v. Superior Court, 5 Cal. App. 3d 811, 85 Cal. Rptr. 744 (1st Dist. 1970). 
bearing on cases such as that of Angela Davis, where counsel vigorously support the defendant's request for a form of self-representation. ${ }^{175}$

Even in cases where the attorney inust accept advisory status, however, the justification for forcing the defendant to choose rests on supposed difficulties in defining the appropriate professional responsibilities for attorneys who do not have exclusive control over the management of their cases. The difficulties are, however, more apparent than real. In Chicago v. Kiger, ${ }^{176}$ for example, the court had no difficulty in rejecting a pro se defendant's contention that he was inadequately represented by advisory counsel because of the latter's failure to object to hearsay evidence introduced by the prosecution. ${ }^{177}$ In any event, these potential difficulties are also present when the court, of its own discretion, appoints advisory counsel. Furthermore, whatever difficulties do exist can be resolved without forcing the defendant either to do without assistance entirely or to give up taking part in his defense. For example, the court can request counsel to consult with the defendant out of court-before trial and during recesses or whenever the defendant is willing to listen-but to sit mutely at the defense table unless the judge asks him to take over part or all of the case because of the defendant's inability to represent himself. If both the attorney and the defendant want counsel to play a more active role at trial without prejudicing the defendant's right to participate, a form of co-counsel relationship could exist subject to the court's discretion in ruling on the number of counsel for each side who will be allowed to question each ivitness, argue to the jury, offer motions, and raise objections. The attorney's civil and professional liability would be made commensurate with the role he fulfills.

This solution assures that the continuity and fairness of the trial will not be disturbed and at the same time preserves the defendant's right to participate. In so doing, it ineets the enlightened standard expressed in People v. Ruiz: "[T] he state should keep to a necessary

175. People v. Mattson, 51 Cal. 2d 777, 336 P.2d 937 (1959), the principal California case interpreting the state's constitutional clause to provide an either-or right to defend pro se [see text accompanying note 94 supra] can be distinguished from Davis. The Mattson holding applies only to cases in which the trial court appoints counsel for an indigent defendant. $51 \mathrm{Cal} .2 \mathrm{~d}$ at 782, $336 \mathrm{P.2d}$ at 941 . In the Davis case, her lawyers are privately retained. They supported her ultimately successful petition for cocounsel status.

176. 264 N.E.2d 488 (Ill. App. 1970).

177. Id. at 491 :

This argument assumes that the assistant public defender was defendant's counsel whereas, in fact, the record shows that the trial court always recognized that the defendant was representing himself as he had a right to do and the assistant public defender was serving only as an adviser. When the defendant elected to proceed pro se, he assumed responsibility for the legal consequences of his decision. 
minimum its interference with the individual's desire to defend himself in whatever manner he deeins best, using any legitimate means within his resources . . . ."178

Another reason, not articulated in the cases, for forcing a defendant to choose between representation by counsel and pro se seems to be a feeling that defendants should not be allowed to eat their cake and have it too. However, if both the pro se defendant and the integrity of the system benefit froin allowing him access to counsel, a stronger interest than soine vague notion that he is getting away with too inuch should be demonstrated before denying joint representation.

That interest arguably may be that all criminal defendants should be represented exclusively by counsel. In California, legislation amending the state constitution to delete the explicit guarantee of a right to represent oneself is pending. ${ }^{179}$ The rationale for such legislation is not difficult to understand. Given the important philosophical and practical policies in favor of professional representation expressed in Gideon, the perceived delay, expense, and affront to the dignity of bar and bench concomitant with pro se representation justify transforming an individual protection into a societal norm. After all, it is argued, imposition of counsel is for the defendant's own good.

The difficulty with this analysis is twofold: the theory of protecting individuals in society through protection of society as a whole is a distortion of the constitutional guarantees of individual liberty; inore important for present purposes is the realization that the assumptions underlymg this incursion into the realm of individual choice are not clearly warranted. Defendants do not have equal ability to organize and present their cases; the nature of acts prosecuted as criminal varies greatly; important differences exist among attorneys, all of whoin are "qualified" to represent criminal defendants, in terins of their skills, resources, and willingness to assure that the defendant's best case is put forward.

\section{CoNCLUSION}

Until the realities of legal representation more closely approximate the adversary inodel, the solution is not to ignore the natural

178. People v. Ruiz, 263 Cal. App. 2d 216, 227, 69 Cal. Rptr. 473, 480 (2d Dist. 1968) (reversing conviction on the ground that defendant was improperly denied the opportunity to represent himself), quoting People v. Crovedi, 65 Cal. 2d 199, 207-08, 417 P.2d 868, 874, 53 Cal. Rptr. 284, 290 (1966).

179. On April 1, 1971, California Senator Cologne introduced bills to aniend the state penal code and constitutional provisions guaranteeing the right to represent oneself pro se. The constitutional amendment would grant the legislature "power to require the defendant in a felony case to have the assistance of counsel." S.C.A. 42, Cal. Reg. Sess. (1971) (proposed constitutional amendment). See also S.B. 839, Cal. Reg. Scss. (1971). 
differences in ability among defendants and attorneys, but to compensate by allowing each defendant to choose the means of presenting his best defense. In most cases, this may mean permitting an attorney to have complete control of the defense. In others, the defendants should, if they wish, have substantial control over-and responsibility for-the preparation of their cases, with the assistance of counsel. Whatever formula is arrived at, the choice should be left with the defendant until he proves to be incompetent to choose or unable to abide by reasonable procedures.

This system of representation offers the defendant a realistic chance of having his best defense presented. In so doing, a necessary element of the adversarial procedure for acquitting the innocent and convicting the guilty is established. Hence, both the reality and the appearance of justice are enhanced. Over time, a restored sense of confidence in the judicial system should enable the system to function more efficiently and fairly, perhaps obviating the desires for self-representation. 